cyclone becomes mixed with the colder air as it is rising, owing to the whirling motion : as a result of this, the formation of clouds must be most dense in the centre of the cyclone, and thinner towards its periphery. The latent heat liberated during the condensation accompanying cloud-formation is only obvious in the anticyclone, since it merely slows the rate of cooling in the rising current of air; on the other hand, the cold rain-drops as they fall cool the lower layers of air in a cyclone, so that as a result of the above a mixed convection of heat takes place from the cylone in the direction of the anticyclone. These thermo-dynamic con siderations explain in general a large number of meteorological phenomena of which the speaker was only able to enumerate a few.-Dr. Budde made some remarks in connection with Janssen's communication to the last meeting of the British Association on the double spectrum of oxygen, of which one is proportional to the density of the gas, the other to the square of that density. He showed that on the supposition that one of the spectra is due to separate free molecules, the other to molecules which are impacting, the result must follow which Janssen has found experimentally.

Physiological Society, November 23.-Prof. du Bois Reymond, President, in the chair. - Prof. Moebius spoke on the nests which are constructed by the marine stickleback (Gastero. steus). As early as 1829 the fact that this animal constructs a nest was described by an English observer. The speaker had had frequent opportunities of examining these nests in the Baltic, and found that they are constituted not only out of Fuci, Algæ, and other marine plants, but also out of the leaves of terrestria plants which have faller into the water, and even sometimes out of bits of wool. The male, who is constantly circling round the nest, knows how to find it again, even if it is lifted and lowered again into the water at a distance of five hundred paces from its first position. In an aquarium the speaker was able to observe that the male is continually spinning new fibres round the nest which proceed from out of the urinary bladder. The fibres are, as shown by chemical reactions, composed of mucin, which is not, however, secreted in the bladder, but by the kidneys. Sections through a kidney, treated with osmic acid and stained with hrematoxylin, showed that only a few of the cells lining the uriniferous tubes are concerned in the elaboration of mucin, the others undergoing no such change. Out of the breeding-season none of these mucigenous cells are to be found in the kidneys, which are then less swollen. A case analogous to the above, of nests constructed of mucin derived from temporarily modified gland-cells, is found in Salangane, which produce the edible nests; these birds make use of a glutinous material for the construction of their nests, which is at times secreted by a gland, in this case the salivary gland. A comparative physiological-chemical analysis of these two secretions would be very interesting.-Prof. Munk gave an account of his researches on the physiology of the thyroid gland. It has long been known that in cases of excision of this gland in man the patients suffer from severe cachexia, to which they speedily succumb, with symptoms indicative of serious disease of the central nervous system; this fact has led to a long series of physiological researches, from which it appears that this small organ is of the greatest importance to life. It was assumed, in accordance with Schiff's views, either that it produces some substance which, passing into the blood, upsets the normal function of the central nervous system, or that it is concerned in the destruction of some injurious products of cerebral activity. Two years ago, as the speaker began his researches on the physiology of this gland, with a view to the discovery of the above remarkable substance, he observed solitary cases in which the dogs were only slightly ill, and then completely recovered, notwithstanding that the thyroid was completely extirpated; one dog showed no signs of any illness at all. Similarly in the literature of this subject, solitary cases are mentioned in which extirpation had no effect on the dog's health. The speaker had next changed his method of operating, merely isolating the gland from the surrounding structures, ligaturing the hilus, and replacing the isolated lobes in their original position. Some of the dogs with the gland thus isolated lived on in perfect health; in these the gland was found to have degenerated and become completely converted into connective-tissue. Others of the dogs became ill and died, and in these the gland had healed and recovered its vascular supply. From these experiments it followed that the thyroid is not an organ of absolute importance for life, inasmuch as animals can live in perfect health without it. It thus remained to determine what is the cause of the serious pathological condition and ultimate death which ensues when the thyroid is excised in man and other animals. A careful study of the symptoms showed that the normal functions of respiration, cardiac activity and nutrition, and of the nervous system, are upset, resulting in dyspnoea with powerful expirations, palpitation of the heart, relaxation of the arteries, derangement of the movements of deglutition, accompanied by vomiting, clonic and tonic cramps, resulting in epileptic attacks. It was further found that the dyspnœa and palpitation are primary symptoms, the cramps are secondary, and that death ensues during the latter. The dyspnœic attacks with the resultant conditions are undoubtedly due to the stimulation of nerves lying in the inflamed tissues after the extirpation of the gland, viz. the superior laryngeal, recurrent laryngeal, vagus, and sympathetic nerves. This is clearly shown by the fact that when the gland is simply isolated by a ligature the dogs live in good health, the gland at the same time degenerating, whereas in cases where the surrounding tissues inflame and lead to a renewed adhesion and vascularity of this organ the dogs became ill and diecl. The speaker was obliged to defer to the next meeting, owing to the lateness of the hour, the further description of his experiments, and of the conclusions to be drawn from them.

\section{BOOKS, PAMPHLETS, and SERIALS RECEIVED} The Mining Manual for $x 888:$ W. R. Skinner.-The Speaking Parrots,
parts 7 and 8 : Dr. K. Russ (L. U. Gill). - British Dogs, Nos. 25 and $26: H$. Dalziel (L. U. Gill) - A T ext-book of Elementary Metallurgy : A. H. Hiorn (Macmillan).-Mental Evolution in Man: G. J. Romanes (Kegan Paul). Die Stämme des Thierreiches (Wirbellose Thiere), vol. ii.: M. Neumay (Temsky, Wien). -Essai d'une Théorie Rationnelle des Sociétés de Secour Mutuels : P. de Lafitte (Paris, Gauthier-Villars).-Cours d'Astronomi Pratique; Application à la Géographie et à la Navigation, 2me partie : E Caspari (Paris, Gauthier-Villars). - The Agreement of Colour Theories with Practical Experience: G. H. Morton (Liverpool). - The Proposed Chemical Practical Experience: G. H. Morton (Liverpool). - The Proposed Chemical
Laboratory at the University of Sydney: A. Liversidge (Sydney). - Journal of the Chemical Society, December (Gurney and Jackson).-Proceeding of the Linnean Society of New South Wales, vol. iii. part I (Trübner).

\section{CONTENTS.}

PAGE

The Zoological Results of the Challenger Expedition 145 The British Farmer and his Competitors .... I46 Coleoptera

Our Book Sheif :-

Casey: "A Sequel to the First Six Books of the Elements of Euclid" ". . - . . 14 48

Abbot: "Elementary Theory of the Tides" "Pictures of Native Life in Distant Lands" . . . . . . . . . . . . 148 Wood : "The Zoo" . . . . . . . . 148

Wise: "Alpine Winter in its Medical Aspects" ". 148

Furneaux: "Animal Physiology" . . . . . . I48 Letters to the Editor:-

Hailstones. (Illustrated.)-Alexander Johnstone. 148 The Renaissance of British Mineralogy.-Prof. W. N. Hartley, F.R.S.

"Weather Charts and Storm Warnings."-Joseph John Murphy

The Philippine "Tamarao." $\dot{-A}$ H. Everett. . I49

A Pheasant attacking a Gamekeeper.-M. H. Maw I50 The Morphology of Birds. I. By Dr. H. Gadow . I5O Statistics of the British Association. (With $a$

Diagram) ....... I52

The Movements of Cyclonic Areas ...... I54

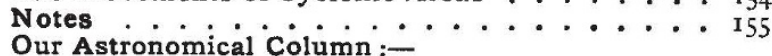

Comet 1888 e (Barnard, September 2) . . . . 158

Y Cygni . . . . . . . . 158

Recent Sketches of Jupiter . . . . . . . 158

85 Pegasi . . . . . . 158

Astronomical Phenomena for the Week 1888

December 16-22 . . . . . . . . . . . 158

Geographical Notes ......... 159

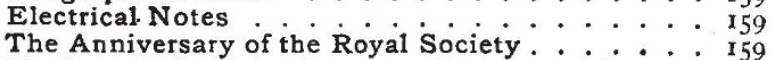

Motions of the Solar System. By Ormond Stone . 162

University and Educational Inteligence . . . 164

Scientific Serials ............. 164

Societies and Academies . . . . . . . 165

Books, Pamphlets, and Serials Received : : 168 